\title{
Well-applied local governance in an urban area
}

\section{Standard tata kelola pemerintahan daerah di kawasan perkotaan}

\author{
Ridho Al-Hamdi \\ Department of Government Affairs and Administration, Faculty of Social and Political Sciences, \\ Universitas Muhammadiyah Yogyakarta \\ Address: Jalan Brawijaya, Tamantirto, Kasihan, Bantul, Yogyakarta 55183 \\ E-mail: ridhoalhamdi@umy.ac.id
}

\begin{abstract}
This paper analyses the application of local governance in addressing education and health affairs in contemporary Indonesia. There are three main objectives: explaining the development of local governance, finding out the impact of the local governance on public services, and investigating driving factors that influence the local governance application. Methodologically, it is qualitative research by employing a case study. Therefore, the Yogyakarta municipality was selected as the study object due to its outstanding achievements, such as the city cleanest of corruption (2009-2010), the most livable city in Indonesia (2010-2011), and the top rank of the Indonesian governance index (2014). In-depth interviews of eight informants and documentary methods are utilized as data-gathering techniques. The study's finding is threefold; first, the development of the municipal government can be divided into three steps: the phase of installation of democratic systems, the phase of plentiful signs of progress, and the stable situation. Second, the impact of the governance process on education and health issues is increasing the municipal budget from year to year, supporting facilities, integrated systems, and the pro-poor people policy. Third, a fourfold determining factor that can influence the successful governance: the city mayor's leadership, a good partnership and cooperation amongst governance actors, the availability of well-educated civil servants, and the maximization of local-owned resources.
\end{abstract}

Keywords: local governance; public service; education; health

\begin{abstract}
Abstrak
Artikel ini mengkaji tentang penerapan tata kelola pemerintah daerah di Indonesia dalam menghadapi dua isu utama dalam pelayanan publik, yaitu pendidikan dan kesehatan. Ada tiga tujuan utama: menjelaskan tentang perkembangan tata kelola pemerintahan lokal, menganalisis tentang dampak tata kelola lokal terhadap pelayanan publik, dan menelusuri faktor-faktor penentu yang mempengaruhi keberhasilan penerapan tata kelola pemerintahan lokal. Metode penelitian ini adalah metode kualitatif dengan menggunakan pendekatan studi kasus. Kota Yogyakarta dipilih sebagai obyek kasus yang diteliti karena prestasinya yang luar biasa seperti kota terbersih dari korupsi (2009-2010), kota paling nyaman ditinggali di Indonesia (2010-2011), dan indeks terbaik dalam hal tata kelola pemerintahan (2014). Wawancara mendalam ke delapan narasumber dan dokumentasi adalah cara yang digunakan untuk pengumpulan data. Temuan penelitian ini menunjukkan tiga hal, pertama, perkembangan tata kelola pemerintahan lokal dapat dibagi menjadi tiga tahap: fase penerapan sistem demokrasi, fase munculnya perkembangan positif, dan fase kondisi stabil. Kedua, dampak dari tata kelola pemerintahan terhadap isu pendidikan dan kesehatan adalah meningkatnya Anggaran Pendapatan dan Belanja Daerah (APBD) dari tahun ke tahun termasuk di dalamnya fasilitas pendukung, sistem yang terintegrasi, dan kebijakan pro rakyat miskin. Ketiga, ada empat faktor penentu yang dapat mempengaruhi keberhasilan tata kelola: kepemimpinan walikota/bupati, kerjasama yang baik, dan kooperatif di antara para kator tata kelola tersebut, ketersediaan sumber daya Aparatur Sipil Negara (ASN) yang terdidik, dan mengoptimalkan Pendapatan Asli Daerah (PAD).
\end{abstract}

Kata kunci: tata kelola daerah; pelayanan publik; pendidikan; kesehatan

\section{Introduction}

The political circumstance in Indonesia altered drastically after the breakdown of authoritarian rule in 1998. Law No.22/1999 on the regional government issued by the Habibie administration, where this Law bestowed the district and municipal governments with comprehensive authorization to administrate their local matters. Although the Law was revised twice by Law No. 32/2004 under 
President Megawati and by Law No.23/2014 under President Yudhoyono, these Laws continue to give a high authorization to regional governments to govern their local resources (Kementerian Sekretariat Negara 1999, 2004, \& 2014). Hence, researching the current development of local governance after two decades of Indonesian democratization since 1998 is an appealing issue. Although some scholars, such as Ramage (2007), Aspinall (2013), \& Mietzner (2013), are optimistic about the future of Indonesian democracy, Winters (2013) predicted that the prospect of democratic consolidation in Indonesia is equally grim. Winters' thesis is supported by other scholars who found that new feudalism and a patronage system are growing in many provinces, districts, and municipalities (Buehler \& Tan 2007, Choi 2007). Thus, Hadiwinata \& Schuck (2007) labeled Indonesian democracy as oscillating between defective and consolidated. Nonetheless, some of Indonesia's cities are growing in a positive path. According to research conducted by Gismar et al. (2013) on the Indonesia Governance Index (IGI) at the provincial level across Indonesia, Yogyakarta Special Region (DIY) reached the top IGI national rank in 2012 amongst 33 provinces, followed by East Java and Jakarta in the second and third IGI ranks.

Gismar et al. (2014) released the IGI at municipal and regency levels across the country. The research finding revealed that among 34 selected districts and municipalities, the Yogyakarta municipality selected as Indonesia's best city in achieving the IGI's highest degree. The Semarang municipality and Gunungkidul District gained the second and third ranks. These districts and municipalities selected by considering representative high, middle, and low levels of their Human Development Index (HDI). In addition to HDI, to measure the leadership effectiveness of local bureaucrats, the IGI also utilized the guidance on the Evaluasi Kinerja Penyelenggaraan Pemerintahan Daerah (EKPPD) or Evaluation of the Local Government Performance published by Indonesia's Ministry of Home Affairs.

Maarif Institute (2016) carried out empirical research on the Islamic values-based city index amongst 29 Indonesian municipalities. The research finding proved that the Yogyakarta municipality, Bandung municipality, and Denpasar municipality gained the first, second, and third positions. Respectively, as Islamic values-based cities in Indonesia. The research applied three significant indicators, namely secure, prosperous, and happy so that, considering these, an Islamic values-based city can be conceptualized as a secure city, a prosperous city, and a lively city. Despite triggering a variety of reactions among Indonesian society, whether approval or refusal of this research, Yogyakarta municipality can be considered as the real model of the application of universal Islamic values in a society. Supporting this researches, Pribadi (2013) put forward that citizens in Yogyakarta municipality were satisfied with the municipal government's public services. In addition, Zuhriyati \& Rahmawati (2014) and Yunus et al. (2016) postulated that transformational leadership in the local government is one of the most crucial factors in realizing public governance and government innovation.

The object of the research is the Yogyakarta municipality due to its overwhelming growth. Three objectives will be earned from this study: 1) is to figure out the development of local governance in current Indonesia between 2001 and 2015,2) is to understand the impact of local governance on education and health issues, and 3 ) is to find the determining factors which influence the successful realization of local governance. Thus, the paper's significance is discovering the real practice of administering local public services so that other local governments can adopt this at national and international levels. No one research demonstrates the best practice of local governance in developing countries, particularly in Indonesia, so that this paper attempts to reveal a benchmark for other cities.

Based on the earlier accounts, this paper is concentrating on three interconnected questions: To what extent can the local governance be applied well in the Yogyakarta municipality? What are its impacts on education and health issues? What are the determining factors which can influence the realization of local governance?

\section{Research Method}

This paper applies the qualitative research method (Denzin \& Lincoln 2011, Devine 2002, Glesne \& Peshkin 1992, Patton 2002, Silverman 2001). Among five kinds of qualitative research, namely 
narrative, phenomenological, grounded theory, ethnographic, and case study, this paper prefers to adopt the case study research approach due to its relevance (Berg \& Lune 2012, Creswell 2013, Flyvbjerg 2011, Gerring 2004, Yin 1994). Thus, this paper selected Yogyakarta municipality, the capital of the Province of Special Region of Yogyakarta (DIY), as the case study for a local governance practice in Indonesia. Covering an area of 32.50 square kilometers, as of 2016, the total population in Yogyakarta municipality is 417,744 inhabitants, with 82.84 percent Muslims (Badan Pusat Statistik Kota Yogyakarta 2017). In the meantime, Javanese is still dominating other ethnicities. Nonetheless, through marriage and occupational motives, non-Javanese society has been entering, with even a few foreign people (Al-Hamdi 2017). As one of Indonesia's leading cities, Yogyakarta envisages itself for 2005-2025 as the city with a qualified education, culture-based tourism, and an environment-oriented service center (Pemerintah Kota Yogyakarta 2008).

Concerning the HDI in Yogyakarta municipality, it increased continuously during the three years between 2011 and 2013. It assessed by three core indicators: life expectancy (health), literacy rate and the average length in going to school (education), and the average real spending per capita (economy). The HDI in 2011 was 79.9, it went up to 80.2 in 2012 and reached 80.5 in 2013. On the international scale, and HDI score above 80 can be classified at the top level. This fact eventually positioned it in the national second rank (Badan Pusat Statistik Kota Yogyakarta 2014a). As a result, it earned many awards with more than ninety prizes since 2003 and has achieved various remarkable acknowledgments since 2009. It can be provided here, at least, four relevant recognitions: the city cleanest of corruption in 2009 and 2010, Indonesia's most livable city in 2010 and 2011, the city with a conducive growth in the life expectancy in 2011 and 2013 and Indonesia's best municipality in realizing good governance in 2014 .

In-depth interviews and documentary were employed as data-gathering techniques (Glesne \& Peshkin 1992, Manheim \& Rich 1986, Patton 2002, Silverman 2001, Yin 1994). For the in-depth interview, it was conducted for approximately five months, between June and November 2015. The informant could be interviewed twice. Eight relevant informants were successfully interviewed. They represent local officials, members of parliament, and politicians in the Yogyakarta municipality. More specifically, they are a former mayor (Herry Zudianto), the former vice mayor (Syukri Fadholi), former head of the education agency (Syamsury), secretary of the education agency (Budi S. Asror), former head of the health agency (Tuty Setyowati), head of the local parliament (Sujarnoko, from PDIP party), deputy head of the municipal parliament (M. Ali Fahmi, from PAN party) and a former municipal legislator (M. Zuhrif Hudaya, from PKS party). Meanwhile, the documentary was carried out before, during, and after the field research. Supporting documents coming from municipal government institutions and appropriate scholarly references will also be utilized in this research.

The given data will be analyzed in a fourfold step. First is reducing the data. The data which appear in written field notes will be selected, simplified and, in turn, transformed into the data display. As the second step, displaying data is compressing a set of information that allows depicting concluding remarks. Third is drawing and verification. Since the commencement, the researcher should make a decision on what things mean - noting regularities, patterns, explanations, possible configurations, causal flows, and propositions. Final concluding remarks may not appear until data collecting is done, although the analyst argues to have been proceeding "inductively." The concluding remarks are validated as the researcher proceeds (Creswell 2013, Miles \& Huberman 1994).

\section{Results and Discussion}

\section{The governance application in Yogyakarta municipality (2001-2017)}

The application of local governance in Yogyakarta municipality can be seen in the interaction amongst so-called "governance actors" consisting of four major actors: executive, legislative, civil society, and economic cluster. The first two actors can be categorized as the state actors, while the rest will be grouped as the social actors. More specifically, the local application will be explored in three steps: 2001-2006, 2006-2011, and 2011-2017. In the meantime, the 1998-2001 period is the transition phase from the dictatorship to the democratic regime wherein, during this period, the local government cannot be realized constitutionally. 
This paper applies Huntington's (1991) standard of democracy to measure the development of municipal governance. The standard comprises three interrelated stages: the end of an authoritarian regime (0-4), the installation of a democratic regime (4.1-7), and the consolidation of the democratic regime (7.1-10). These three stages will be rated on the scale of 0 (very poor) to 10 (very good). This scale is a standard measurement that was 0 for the lowest score, while ten is the highest. Figure 1 depicts the positive growth of municipal governance between 2006 and 2011 following the earlier period wherein the position is consolidated democracy. Nevertheless, a slight regression took place in the following period, falling for one scale from 7.5 to 6.5 .
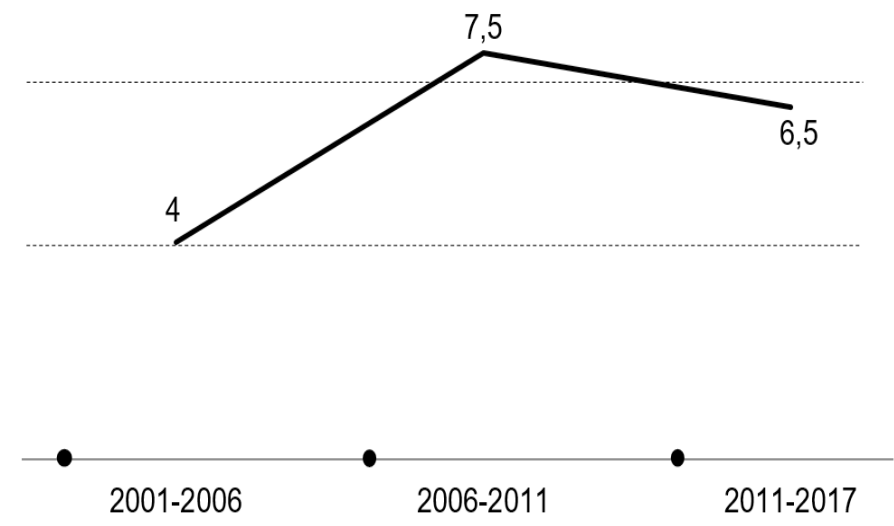

Figure 1.

The Governance Application in Yogyakarta Municipality in 2001-2017

Source: Compiled by the Author

\section{Conflict frequency: 2001-2006}

In this phase, Herry Zudianto and Syukri Fadholi were the elected mayor and vice mayor. During five years, the conflict was usually at a high temperature between the municipal government and three other actors: legislature, civil society, and industrial society. It can be proved in two main cases. First is the rearrangement of Pedagang Kaki Lima (PKL) or street-based vendors and traditional markets. These cases afford some instances during this period. The municipal government wished to reposition numerous $P K L$ s and traditional markets between 2001 and 2002, mainly surrounding Malioboro Street and the shopping center close to the Beringharjo traditional market. The impact was that many stakeholders rejected this government design. Society presumed that the municipal government would evict those traders and markets from the city, and several protest rallies occurred in the city streets.

The conflict heated up at the upper level when the municipal government proposed to close nightclubs, discotheques, casinos, the drug trade, and prostitution. These spots were rampant within the city from the 1980s to the initial 2000s, so that the Mayoral Regulation No.74/2003 on the closing of nightclubs and casinos was issued by the Pemerintah Kota Yogyakarta (2003) to diminish this industry. Simultaneously, the municipal government formed an ad hoc squad to keep an eye on this regulation in society. This team performed excellently and, therefore, a number of those places were closed. Most industrialists and workers protested the regulation and the squad's actions, even demonstrating in the streets. They robustly insisted that the municipal government revoke the regulation because the people who worked in those areas were jobless. The impact, because this period was still in the process of installation of democratic systems, was that public services could not be implemented well due to vertical and horizontal barriers.

\section{Moving toward a consolidated governance: 2006-2011}

The conflict which took place in the preceding period seems to be reduced, as the municipal government endeavored to consolidate and communicate any matters with all related stakeholders. The re-elected Mayor, Herry Zudianto, seemed to succeed in fostering communication with all segments of governance actors. He implemented many signs of advancements, and the municipal 
government received various awards under his administration. As a result, Zudianto became an influential figure inside the municipality. He could be in command of all stakeholders inside the city. Even though different points of view still existed, which is common, the clash did not look too pronounced compared to the prior era.

After three years of administering the municipality since 2001, Zudianto plunged straight into society and discussed with people on any topics before going to the city hall and undertaking regular activities. The public could converse with him by telephone and social media. He read daily newspapers to discover the latest situations and chatted with all kinds of mass media weekly to tell them the real circumstance. In brief, he desired to listen to society's aspirations. Therefore, 70 percent of the sources of the ideas formulated by Zudianto to make a decision was derived from people's grievances and desires. An illustration was the case of the Beringharjo market rearrangement in 2004; this was a complicated process for him to reassure society, as a change in life is commonly feared by each person. Considering these facts, he endeavored to present himself as they were, as a laborer, as a street peddler, and so forth. Zudianto was sure that people oy disagreed with him because of a lack of information. In this period, the interaction among these four actors went to positive development and, in turn, moved toward the consolidated governance. Various achievements were made, as was depicted in the research method.

\section{Stable situation: 2011-2017}

The governance application during this period was quite stable, although the four governance actors still addressed some barriers. It can be known in the early leadership of the elected mayor, Haryadi Suyuti. His performance demonstrated a poor impression, mainly among Muslim communities, despite coming from a devout Muslim family. For instance, he avoided an invitation from Muhammadiyah, one of the influential Muslim organizations in Indonesia, while preferring to attend a non-Muslim activity at the same time. Moreover, the financial assistance to Muslim communities in this era was decreased by the municipal government rather than as had previously been the case. It cannot be separated from his presence in the government.

Nonetheless, approaching the closing stages of his administration, Suyuti seemingly came close to the Muslim community, as shown when he engaged himself in the case of horizontal conflict between the Muhammadiyah Karangkajen Junior High School and the society surrounding the school in January 2016. There are two main reasons why Suyuti stood up for the Muhammadiyah school. First was the dissonance between Suyuti and his vice mayor, Putranto. Second, he required the political backing of Muhammadiyah for the 2017 mayoral election. The upshot was the conflict suffered amongst the governance actors. Nonetheless, the development of municipal governance was stable, as it suffered a slight regression under the consolidated democracy.

\section{The governance impact on education and health issues}

It is essential to be present here the impact of the municipal governance on public services. This paper selects two fundamental public service issues in Yogyakarta Municipality: education and health.

\section{Education affairs}

Yogyakarta Municipality is widely known as Indonesia's city of education. Nevertheless, before 2002 , the municipal government did not vigorously encourage education programs. It can be seen from its budget plan in 2002, which was below five percent, and also proved by the less attention paid to the importance of providing an excellent education for people. Fortunately, the budget for education affairs in the following years increased continuously from 12.53 percent in 2004 to 22.26 percent in 2007. Although it progressed dramatically to 40.07 percent in 2015, in the two following years, it fell to 39.26 percent in 2016, and 29.63 percent in 2017. However, it denotes the fact that, since 2007, the budget for education issues has already gone beyond the national minimum standard of 20 percent (Pemerintah Kota Yogyakarta 2008). 
The municipal government conducted many programs. First was providing pupil scholarships from kindergarten to secondary school. The second was providing budgets to cover school needs to avoid a quality gap among schools. The third was improving teachers' wages and status, fourth was increasing pupils' nutrition, and fifth was the application of technology-based to facilitate the new pupil registration since 2006 and online learning consultation. Sixth was the provision of funds for the early childhood education or Pendidikan Anak Usia Dini (PAUD), and seventh was the establishment of the Taman Pintar in 2008 as a public sphere to learn about science and technology. The park became the icon of educational tourism within the municipality and, in turn, strengthened Yogyakarta's image as the city of education (Pemerintah Kota Yogyakarta 2008).

Regarding education facilities, the highest number of schools in 2014 was primary schools with 169 units. In contrast, the lowest number was the vocational school with 32 units. Moreover, the number of private schools was higher than in public schools except for primary schools. Private sectors had a significant role in progressing education affairs and reinforced the epithet of the city of education. The most interesting is that the municipal government seemingly paid less attention to the development of kindergartens. Public kindergartens had merely two units. In addition, based on data from the Badan Pusat Statistik Kota Yogyakarta (2015), the municipality in 2014 had 37 colleges, both public and private, with various faculties and departments. In the second semester of 2014, it had 45.385 students and 1.583 lecturers. Concerning literacy, it increased from 97.38 percent in 2011 to 98.52 percent in 2013 (Badan Pusat Statistik Kota Yogyakarta 2014b). It is a tremendous achievement. Moreover, in 2013, the rate of school participation reached 98.84 percent for the primary school, 87.36 percent for junior high school, and 69.04 percent for senior high school (Badan Pusat Statistik Kota Yogyakarta 2015). It reveals that the higher the school level, the less the students participate in going to school.

According to the Secretary of the Education Agency in Yogyakarta municipality, Budi S. Asror, other remarkable developments were achieved, such as the program of twelve years of compulsory education. Therefore, no child inside the municipality could not reach the minimum of secondary school level. As a result, children from low-income families were subsidized by the municipal budget. In 2015, the monthly tuition fee for the senior high school was 40.000 IDR (just under 3 EUR). In addition, the municipal government created the Penerimaan Peserta Didik Baru (PPDB) or New Pupil Registration Online System and the Real-Time Online (RTO) system in 2004. With these systems, all pupils battle each other without knowing their social background. Probably, pupils coming from wealthy families could not succeed in entering the favorite schools. Up to 2016, the number of schools in Yogyakarta municipality was 225 kindergartens, 168 elementary schools, 144 secondary schools, vocational classes, and nine excellent schools. In addition, there were 35 campuses with a variety of faculties and departments. In the second semester of 2015, there were 50.362 students, and in 2016 there were 1.853 lecturers (Badan Pusat Statistik Kota Yogyakarta 2017). Those schools and campuses consist of both public and private institutions.

\section{Health affairs}

Before 2003, the health service in Yogyakarta Municipality was dreadful for poor people. It was triggered by the weak data on poor people so that health services could not stretch to accommodate them. The first health service for children, mothers, and older people were also not optimal. It cooccurred with the reduction of the Integrated Service Centre's role or so-called Posyandu in providing initial health services. In addition, several impediments were also addressed by the municipality, such as a range of infectious diseases and the tiny budget for health insurance programs (Pemerintah Kota Yogyakarta 2008).

The municipal government had already executed some agendas related to health affairs. First was the implementation of Jaminan Kesehatan Daerah (JAMKESDA) or Regional Health Guarantee system for poor people. In doing so, the municipal government issued the Kartu Menuju Sehat (KMS) or Card Towards Health Group program. It was primarily for needy residents in the municipality. If the residents come to the health centers, they only had to show the $K M S$, and, in turn, there was no payment. All 
poor people thus obtained health services. The second was the revitalization and development of the Posyandu or Integrated Healthcare Center as the public health service for babies, pregnant mothers, and older people. The other function of the Posyandu could be used for parenting education. The third was providing additional food for children (from baby to primary school level) to increase their nutrition. To execute this program, the municipal government involved the school committee and the Puskesmas or Public Health Center. The fourth was the implementation of Perilaku Hidup Bersih dan Sehat (PHBS) or Clean and Healthy Behavior for students in the school. There were two activities: 1) the municipal government-supplied faucets for each school to increase healthy behaviors among students, and 2) the implementation of "Semutlis" for students to clean the school for ten minutes. The fifth was the establishment of the NCC collaborating with Indonesia's Gerakan Anti Narkoba (GRANAT) or Anti-Narcotics Movement and the Karang Taruna or Youth Organization to counter drug abuse the young generations. The sixth was granting 500.000 IDR for each person with tuberculosis and their caretakers to stimulate their life to be a healthy human (Pemerintah Kota Yogyakarta 2008).

However, growth was achieved in the following years in various aspects. First is the life expectancy during the three years from 2011 to 2013. Babies born between 2011 and 2012 have a life expectancy of up to 73.48 years old and 73.51 years old, respectively (Badan Pusat Statistik Kota Yogyakarta 2014a). Second is that the percentage of the nutritional status of children under five was in growth in the seven years between 2010 and 2016 (Badan Pusat Statistik Kota Yogyakarta 2017). The third was making it free of charge for deprived people having municipal citizen ID if they went to public health centers based on the legal regulation. Fourth, the municipal budget for health affairs in the last three years increased: 13.27 percent in 2015, 17.33 percent in 2016, and 19.13 percent in 2017. It is the second priority budget after the education sectors.

By 2016, health facilities in this municipality were provided with an adequate number. There were 20 hospitals, 27 public health centers, so-called as Puskesmas, 85 polyclinics, 1.811-bed capacity consisting of 303 in public hospitals, and 1.508 in private hospitals, 127 dispensaries, and 27 pharmacies. The number of health workers based on work units and health service facilities in 2016 was 748 doctors, 2.302 nurses, 298 midwives, 369 pharmacists, 104 nutritionists, 429 medical technicians, 51 personnel in sanitary, and 18 public health degrees. In particular, the doctors within the municipality consisted of 593 specialists, 460 general doctors, 134 dentists, and 78 dental specialists (Badan Pusat Statistik Kota Yogyakarta 2017).

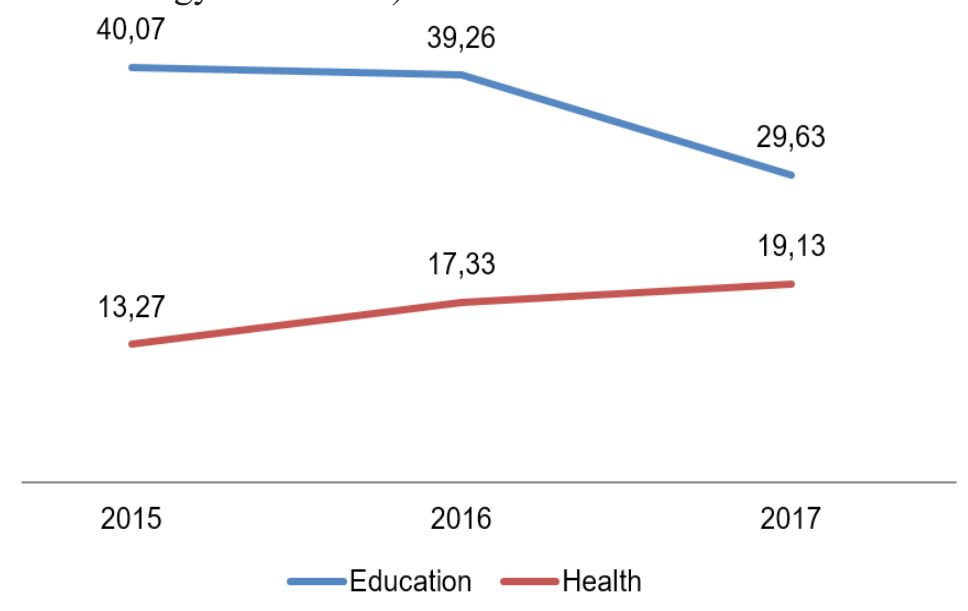

Figure 2.

The Percentage of Annual Budget for Education and Health Sectors between 2015 and 2017 Source: Compiled by the Author

Figure 2 illustrates the fact that, for three years, from 2015 to 2017, the annual budget for education and health sectors was always reaching roughly half of the total annual budget. This budget also puts those two issues in the first and second ranks as opposed to other sectors. While the budget for education sectors was decreasing during this time, Figure 2 essentially postulates that education and health issues are two vital public services where the budget for both should at least be equal to each other. Hence, there is no distant discrepancy in the budget for both sectors. 


\section{Determining factors}

There is a fourfold determining factor influencing the successful application of the local governance in the Yogyakarta municipality. First is the city mayor's leadership, there are four elemental principles of successful leadership: 1) a vision must be possessed by the leader, as he or she can sway others, 2) arrogance should be avoided by the leader and listening to people more and more is preferable, 3) being afraid is not allowed for the leader when he or she makes a decision, and 4) being a good exemplar in real life so that society will imitate the leader's attitudes. The patron-client relation in Indonesia is still vigorous rather than building an integrated system. Thus, the leader belongs to all people, not individual communities or ethnicities or religions; otherwise, the governance will suffer a regression.

The second is a good partnership and cooperation between the municipal government and parliament in executing various local agendas. There are three periods of the regional government in the Yogyakarta municipality between 2001 and 2017. It can be seen with the excellent leadership of the mayor and vice mayor and the way they communicated with almost all factions in the parliament in any program. Meanwhile, there have been four parliamentary periods from 1999 until 2019. Despite suffering a conflict between 2001 and 2006, the relationship between these two wings is quite positive in the following years. A variety of acknowledgments, achievements, and awards are tangible proof. The municipal government's result has been managed and controlled by governance actors: executive, legislature, civil society, and business clusters. This factor supports Mani et al. (2016), finding that the cultural dimension is essential in implementing successful communication among governance actors.

The third is the availability of well-educated apparatus and civil servants. It is undoubtedly related to the way those civil servants are recruited. Good recruitment consists of, at least, graduated from a BA degree, the relevant education for the requirement, and the selected apparatus not because of tribal or blood ties. Hence, the model of human resource recruitment affects the governance process. The given statistical data demonstrates that the number of civil servants under the regional government of Yogyakarta Municipality in 2016 was dominated by bachelor and master degrees with 49.38 percent, followed by diploma degrees, secondary and primary school degrees, respectively (BPS Kota Yogyakarta 2017). Moreover, most civil servants at the sub-district level of the Yogyakarta Municipality are college graduates with 62.06 percent consisting of diploma, bachelor, master, and doctoral degrees while the rest is secondary and primary school graduates (Badan Pusat Statistik Kota Yogyakarta 2017). It indicates that most human resources that have been working in this municipality are well-educated persons.

The fourth is maximizing local-owned resources and other potential factors. By 2017, the municipal income was roughly 1.63 trillion IDR (approximately 98 million Euro if 1 EUR equals to 16.569 IDR, as rated on 26.01.2018). The expenditure was the education sector's peak rank, while the second and third positions were obtained by health and public works-spatial planning sectors. It is quite in line with the positive growth of Yogyakarta municipality as Indonesia's city of education, which is also supported by well-realized infrastructures, well-educated apparatus, and a good leader of the mayor.

\section{Conclusion}

This paper has three main concluding remarks. First, the governance application in Yogyakarta Municipality can pass awkward phases to reach well-applied governance, moving from the conflict circumstance to a stable situation. The upshot is that education and health systems can be realized to fulfill people's fundamental rights. Second, the impact of the governance process on education and health issues is in increasing supporting facilities, integrated systems, the pro-poor people policy, and the municipal budget from year to year. Third, there is a fourfold determining factor that influences the successful governance: the mayor leadership, a good partnership and cooperation between the executive and legislature, the availability of well-educated civil servants, and the maximization of local-owned resources. The real practice, carried out by Yogyakarta Municipality in governing local affairs, can be a national benchmark for other municipalities 
and districts to accelerate their human development and achieve the state and people's welfare. It is essential to be presented here that, after achieving successful governance in education and health services, the Yogyakarta Municipal Government has to pay serious attention to some other public affairs: road infrastructure, transportation, and environment-friendly movements. It aims to support the main functions of municipal government in providing excellent services for society. Real facts cause traffic jams, uncontrolled parking, and narrow streets affect limited spaces for pedestrians as well as emerging some illegal modern markets, and the establishment of a large number of hotels still exist until the present. Thus, the governance actors have to solve those issues and attempt to avoid any conflicts which can retard the governance.

\section{References}

Al-Hamdi R (2017) Indonesian Political Ideology: Political Parties and Local Governance in Yogyakarta Municipality 1998-2015. Baden-Baden: Tectum.

Aspinall E (2013) How Indonesia Survived: Comparative Perspectives on State Disintegration and Democratic Integration. In: M Künkler \& A Stepan (eds). Democracy and Islam in Indonesia. New York: Columbia University Press. 126-146.

Berg BL \& Lune H (2012) Qualitative Research Methods for Social Sciences. Boston \& New York: Pearson Education.

Badan Pusat Statistik Kota Yogyakarta (2014a) Indeks Pembangunan Manusia Kota Yogyakarta 2013. Yogyakarta: BPS Kota Yogyakarta.

Badan Pusat Statistik Kota Yogyakarta (2014b) Indikator Kesejahteraan Rakyat Kota Yogyakarta 2013. Yogyakarta: BPS Kota Yogyakarta.

Badan Pusat Statistik Kota Yogyakarta (2015) Kota Yogyakarta dalam Angka 2015. Yogyakarta: BPS Kota Yogyakarta.

Badan Pusat Statistik Kota Yogyakarta (2017) Kota Yogyakarta dalam angka 2015. Yogyakarta: BPS Kota Yogyakarta.

Buehler M \& Tan PJ (2007) Party-candidate relationships in Indonesian local politics: A case study of the 2005 regional elections in Gowa, South Sulawesi Province. Inside Indonesia, NovDec, Vol 90, 41-69.

Choi N (2007) Election, parties and elites in Indonesian's local politics. South East Asia Research 15 (3):325-354. https://doi.org/10.5367/000000007782717731.

Creswell JW (2013) Qualitative Inquiry and Research Design: Choosing among Five Approaches, Third Edition. Thousand Oaks: Sage Publications.

Denzin NK \& Lincoln YS (2011) Introduction: The Discipline and Practice of Qualitative Research. In: NK Denzin \& YS Lincoln (eds). The Sage Handbook of Qualitative Research. Thousand Oaks: Sage. 1-19.

Devine F (2002) Qualitative Methods. In: D Marsh \& G Stoker (eds). Theory and Methods in Political Science. New York: Palgrave. 197-215.

Flyvbjerg B (2011) Case Study. In: NK Denzin \& YS Lincoln (eds). The Sage Handbook of Qualitative Research. Thousand Oaks: Sage. 301-316.

Gerring J (2004) What is a case study and what is it good for? The American Political Science Review 98 (2):341-354. https://doi.org/10.1017/S0003055404001182.

Gismar AM, Loekman I, Hidayat L, Harjanto N, Suharmawijaya DS, Sulistio H, \& Aritonang RN (2013) Towards a Well-informed Society and Responsive Government: Executive Report Indonesia Governance Index 2012. Jakarta: Kemitraan.

Gismar AM, Hidayat L, Loekman I, Suharmawijaya DS, Harjanto N, Sulistio H, Suwanan AF, Nurdiansah A, Sitanggang AF, Nuril FA, \& Ekawati R (2014) Menata Indonesia dari Daerah: Laporan Eksekutif Indonesia Governance Index 2014. Jakarta: Kemitraan.

Glesne C \& Peshkin A (1992) Becoming Qualitative Researchers: An Introduction. New York: Longman Publishing Group. 
Hadiwinata BS \& Schuck C (2007) Mapping Indonesia's Way towards Democracy: In Search of a Theoretical Frame. In: BS Hadiwinata \& C Schuck (eds). Democracy in Indonesia: The Challenge of Consolidation. Baden-Baden: Nomos-Verlag. 11-27.

Huntington SP (1991) The Third Wave: Democratization in the Late Twentieth Century. Norman: University of Oklahoma Press.

Kementerian Sekretariat Negara. Undang-Undang Republik Indonesia No. 22/1999 tentang Pemerintahan Daerah.

Kementerian Sekretariat Negara Republik . Undang-Undang Republik Indonesia No. 32/2004 tentang Pemerintahan Daerah. Jakarta, Indonesia.

Kementerian Sekretariat Negara. Undang-Undang Republik Indonesia No. 23/2014 tentang Pemerintahan Daerah.

Maarif Institute (2016) Hasil Penelitian Indeks Kota Islami. Jakarta: Maarif Institute.

Manheim JB \& Rich RC (1986) Empirical Political Analysis: Research Methods in Political Science. New York: Longman.

Mani L, Guntoro B, Mudiyono, \& Prajarto N (2016) Cultural dimensions toward the government communications in the policy of street vendors relocation at Yogyakarta City. Indonesian Journal of Government and Politics 7 (4):551-577. http://doi.org/10.18196/jgp.2016.0042. 551-577.

Mietzner M (2013) Money, Power and Ideology: Political Parties in Post-Authoritarian Indonesia. Copenhagen: NUS Press \& NIAS Press.

Miles MB \& Huberman AM (1994) Qualitative Data Analysis: An Expanded Sourcebook. Thousand Oaks: Sage.

Patton MQ (2002) Qualitative Research and Evaluation Methods. Thousand Oaks: Sage.

Pemerintah Kota Yogyakarta (2003) Peraturan Walikota Yogyakarta No. 74/2003 tentang Penutupan Lokasi hiburan dan rumah ketangkasan. Yogyakarta, Indonesia.

Pemerintah Kota Yogyakarta (2008) Best Practices Pemerintah Kota Yogyakarta Periode 2002-2007. Yogyakarta, Indonesia.

Pribadi U (2013) Organizational structure and public service satisfaction in Yogyakarta City. Jurnal Studi Pemerintahan 4 (2):374-389. https://doi.org/10.18196/jgp.2013.0026.

Ramage DE (2007) Indonesia: Democracy first, good governance later. Southeast Asian Affairs 2007 (1):135-157.

Silverman D (2001) Interpreting Qualitative Data: Methods for Analyzing Talk, Text and Interaction. London: Sage.

Winters JA (2013) Oligarchy and democracy in Indonesia. Indonesia 96:11-33.

Yin RK (1994) Case Study Research: Design and Methods. Thousand Oaks: Sage.

Yunus U, Sari SA, \& Patriana RC (2016) Excellent communication in Indonesian government culture to reach good public governance. Pertanika Journal of Social Sciences and Humanities 24 (S):11-18.

Zuhriyati E \& Rahmawati DE (2014) Transformational leadership in the City of Yogyakarta during Herry Zudianto's era. Jurnal Pemerintahan 5 (2):139-151. http://dx.doi.org/10.18196/jgp. 2014.0014. 